\title{
Identification of Risk Factors of Food Losses in Food Processing Plants
}

\author{
By Beata Bilska ${ }^{1}$, Marzena Tomaszewska ${ }^{1}$, Danuta Kołożyn-Krajewska ${ }^{1}$
}

\begin{abstract}
Losses take place along the entire food chain and they need to be analysed and monitored due to their impact on the development of the food sector. In addition to quantitative losses, irrational use of food contributes to the depletion of natural resources (e. g. water and energy) and poses a threat to the environment, constituting a barrier to sustainable development of the food sector. The aim of this study was to establish the causes and effects of food losses in food industry plants and to propose measures for their mitigation. The material for the study was data on losses gathered in six food industry plants located in Poland. The study was conducted on the basis of a survey. In the studied plants, 20 causes of losses were found. A fundamental role in food production is played by access to raw materials of appropriate quality. In any enterprise, the key factor responsible for the commission of errors is human. Food losses affect the food system and its balance in three dimensions: economic, social and environmental - due to the waste of resources used to produce food that is never eaten and due to greenhouse gas emissions. In summary, the risk of food losses must be prevented by eliminating any errors that may result in a product of inadequate quality characteristics.
\end{abstract}

Keywords: food losses, causes of food losses, effects of food losses, food industry plants

\section{Introduction}

As defined in the United Nations Report Our Common Future (Report of the World...1987), sustainable development is development which ensures that present needs are met without depriving future generations of the ability to satisfy their own needs. The European Union's strategy for sustainable development assumes a continuous improvement of citizens' lives, efficient management and use of resources as well as implementation of ecological and social innovations to ensure prosperity, environmental protection and social cohesion (EU Sustainable Development Strategy ...). Sustainable consumption and production forms one of seventeen key indices of sustainable development, the achievement of which is at risk due to the growing use of natural resources and material footprint per capita. Attainment of this important objective is impossible without reducing food losses and waste. At present, there is no commonly adopted definition of these concepts, which would be binding in European or national legal regulations or scientific published papers. Under the definitions offered by the Food and Agriculture Organization of the United Nations (FAO) "food loss" is a decrease in overall weight of food that was designated human consumption. It subtracts quantity of food which was originally produced for consumption but underwent eventually natural loss in weight (e.g. drying), spoilage or was used for another purpose (e.g. to produce biofuel, compost, animal feed and so on). What is not considered 
as loss is inedible parts (e.g. bones, shells, etc.) and raw materials and products initially produced for non-consumption purposes (e.g. animal feed, biocomponents, bioenergy). Apart from food losses, food waste is certainly to be discussed at this point, which is understood as loss in food weight managed at the level of the catering sector and households. FAO has estimated food loss and waste to be $1 / 3$ of the whole of food production, i.e. 1.3 bn of tons (Gustavssons et al., 2011). As the European Commission indicates, 1/3 to 1/2 of the entire food production is lost or wasted globally (i.e. up to 2 bn tons of food). According to Eurostat's rough calculations based on data provided by $27 \mathrm{EU}$ countries, approximately 89 million tons of food waste was generated in 2006 , of which $42 \%$ came from households, 39\% from production, and the remaining 19\% from other sources, including distribution, stores and the catering sector. It is predicted that by 2020 the amount of food wasted in the European Union will increase to roughly 126 million tons if no action is taken to stop this negative phenomenon (Commission Staff Working Document, 2014). As estimated by Eurostat, nearly 35 million tons of food is wasted in processing in Europe and over 6.5 million tons in Poland annually (loss and waste at all levels were estimated to be 9 million tons) (Gustavsson et al., 2011).

Apart from quantitative food losses, irrational use of food leads to overuse of natural resources, contributes to global warming, all the same forming an obstacle to the sustainable development of the food sector on a global scale. Locally, food waste also constitutes a threat to the natural environment, overuse of water and energy, and failure to satisfy food needs of societies.

The aim of this study was to establish the causes and effects of food losses in food industry plants and to propose mitigation measures.

\section{Methodology}

The research was conducted in the first half of 2019. A starting point was to develop a survey as a study tool. Following that, our own research was carried out in six food processing plants located in Poland. In the selection of samples for research, a non-random sampling technique was used, namely targeted selection. Key information about the plants under research is presented in Table 1. Data was collected about, inter alia, the evaluation of factors contributing to food losses, their frequency and causes at nine production stages.

Table 1. Sample characteristics

\begin{tabular}{|c|c|c|c|c|c|}
\hline Code & Sector & $\begin{array}{c}\text { How long business } \\
\text { has been run }\end{array}$ & $\begin{array}{l}\text { Labour } \\
\text { force }\end{array}$ & $\begin{array}{c}\text { Implemented } \\
\text { quality systems }\end{array}$ & $\begin{array}{l}\text { Position of } \\
\text { interviewee }\end{array}$ \\
\hline A & poultry cutting & \multirow{6}{*}{$\begin{array}{l}\text { more than } \\
9 \text { years }\end{array}$} & $\begin{array}{c}\text { more than } \\
1000\end{array}$ & GHP/GMP, HACCP * & $\begin{array}{c}\text { Managing } \\
\text { Director }\end{array}$ \\
\hline B & $\begin{array}{l}\text { production of } \\
\text { chocolate goods }\end{array}$ & & $501-1000$ & GHP/GMP, HACCP* & $\begin{array}{l}\text { Managing } \\
\text { Director }\end{array}$ \\
\hline $\mathrm{C}$ & sugar plant & & \begin{tabular}{|c|} 
more than \\
1000 \\
\end{tabular} & GHP/GMP, HACCP* & $\begin{array}{l}\text { Managing } \\
\text { Director }\end{array}$ \\
\hline $\mathrm{D}$ & meat processing & & $11-99$ & GHP/GMP, HACCP** & $\begin{array}{l}\text { Quality } \\
\text { Manager }\end{array}$ \\
\hline $\mathrm{E}$ & $\begin{array}{l}\text { production of } \\
\text { soft drinks }\end{array}$ & & $11-99$ & $\begin{array}{l}\text { GHP/GMP, } \\
\text { HACCP** }\end{array}$ & $\begin{array}{l}\text { Managing } \\
\text { Director }\end{array}$ \\
\hline $\mathrm{F}$ & production of cereals & & $11-99$ & GHP/GMP, HACCP** & $\begin{array}{l}\text { Quality } \\
\text { Manager }\end{array}$ \\
\hline
\end{tabular}

*HACCP certified $* *$ HACCP non-certified 


\section{Results}

Twenty factors were identified as contributing to food loss in the studied plants (Figure 1, Table 2). In the respondents' opinion, the most significant ones included (an average of at least 3 on a 5-point scale) equipment breakdowns, inadequate quality of raw materials, lack of quality management systems; following that were utility outages. Three factors related to employees were indicated as being of equal significance, namely failure to comply with workstation procedures, lack of training, and improper internal communication. The respondents stated all the identified factors occurred at a low frequency (an average below 2.2 on a 5-point scale). Equipment breakdowns and lack of employee experience were the most frequently occurring factors.

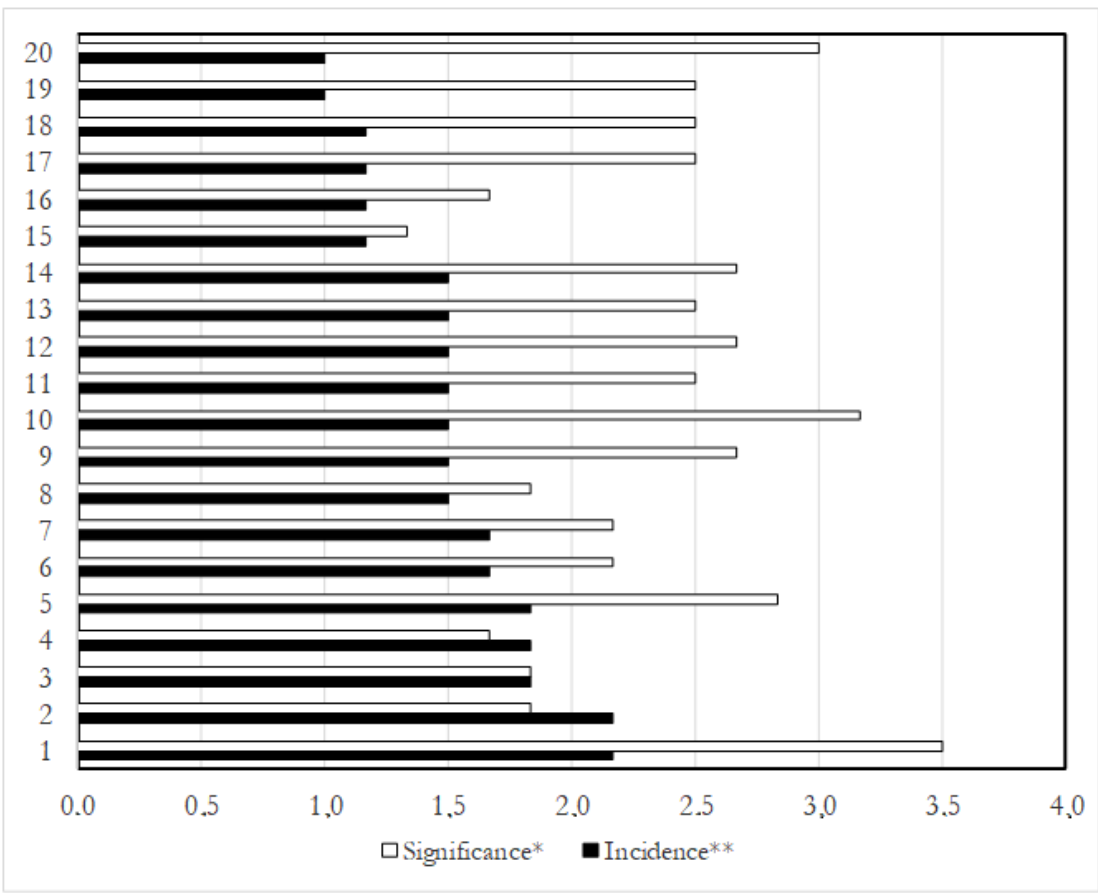

*1 - completely unimportant factor, 2 - unimportant factor, 3 - neither important nor unimportant 4 - important factor, 5 - very important factor

**1 - very rarely, 2 - rarely, 3 - sometimes, 4 - often, 5 - very often

1 - breakdowns, 2 - lack of experience, 3 - lack of commitment to work, 4 - inappropriate education, 5 - utility outages, 6 - inadequate technical condition of devices, 7 - non-compliance with hygienic rules, 8 - no periodic service of devices, 9 - non-compliance with workplace procedures,

10 - inadequate quality of raw materials, 11 - purchase of too many raw materials, 12 - lack of training courses, 13 - lack of relevant qualifications, 14 - incorrect internal communication, 15 absence of suppliers' assessment, 16 - lack of raw materials quality specification, 17 - incorrect external communication, 18 - problems with selling products, 19 - inadequate production technology, 20 - absence of quality management systems

Figure 1. The significance of individual causes and their incidence 
Table 2. The significance of individual causes and their incidence

\begin{tabular}{|c|c|c|c|c|c|c|c|c|c|c|c|c|c|c|c|c|c|c|c|c|c|}
\hline & \multicolumn{20}{|c|}{ The significance* of individual causes } & \multirow[b]{2}{*}{ AV } \\
\hline & 1 & 2 & 3 & 4 & 5 & 6 & 7 & 8 & 9 & 10 & 11 & 12 & 13 & 14 & 15 & 16 & 17 & 18 & 19 & 20 & \\
\hline $\mathrm{A}$ & 3 & 2 & 4 & 3 & 5 & 3 & 4 & 3 & 4 & 4 & 1 & 5 & 4 & 5 & 1 & 1 & 3 & 5 & 1 & 4 & 3.25 \\
\hline $\mathrm{B}$ & 5 & 2 & 2 & 2 & 2 & 4 & 2 & 2 & 4 & 2 & 5 & 4 & 5 & 4 & 2 & 3 & 3 & 2 & 5 & 5 & 3.25 \\
\hline$C$ & 2 & 1 & 1 & 1 & 2 & 1 & 2 & 2 & 2 & 2 & 2 & 3 & 2 & 2 & 1 & 2 & 2 & 2 & 3 & 4 & 1.95 \\
\hline $\mathrm{D}$ & \begin{tabular}{|l|}
4 \\
\end{tabular} & 2 & 2 & 2 & 1 & 1 & 3 & 1 & 3 & 5 & 3 & 2 & 2 & 3 & 2 & 2 & 3 & 1 & 2 & 3 & 2.35 \\
\hline$E$ & 3 & 2 & 1 & 1 & 5 & 3 & 1 & 2 & 2 & 4 & 1 & 1 & 1 & 1 & 1 & 1 & 3 & 3 & 3 & 1 & 2.00 \\
\hline $\mathrm{F}$ & \begin{tabular}{|l|}
4 \\
\end{tabular} & 2 & 1 & 1 & 2 & 1 & 1 & 1 & 1 & 2 & 3 & 1 & 1 & 1 & 1 & 1 & 1 & 2 & 1 & 1 & 1.45 \\
\hline & & & & & & & & & & & & & & & & & & & & & \\
\hline \multicolumn{21}{|c|}{ The incidence** of individual causes } & \\
\hline & 1 & 2 & 3 & 4 & 5 & 6 & 7 & 8 & 9 & 10 & 11 & 12 & 13 & 14 & 15 & 16 & 17 & 18 & 19 & 20 & AV \\
\hline $\mathrm{A}$ & 2 & 4 & 2 & 3 & 3 & 2 & 3 & 1 & 1 & 2 & 1 & 2 & 2 & 2 & 1 & 1 & 1 & 1 & 1 & 1 & 1.80 \\
\hline $\mathrm{B}$ & 1 & 3 & 2 & 2 & 1 & 1 & 2 & 1 & 2 & 1 & 1 & 2 & 2 & 2 & 1 & 1 & 1 & 1 & 1 & 1 & 1.45 \\
\hline $\mathrm{C}$ & 5 & 2 & 4 & 3 & 2 & 4 & 2 & 4 & 3 & 3 & 2 & 2 & 2 & 2 & 2 & 2 & 2 & 1 & 1 & 1 & 2.45 \\
\hline $\mathrm{D}$ & \begin{tabular}{|l|}
2 \\
\end{tabular} & 1 & 1 & 1 & 1 & 1 & 1 & 1 & 1 & 1 & 1 & 1 & 1 & 1 & 1 & 1 & 1 & 1 & 1 & 1 & 1.05 \\
\hline $\mathrm{E}$ & 1 & 1 & 1 & 1 & 3 & 1 & 1 & 1 & 1 & 1 & 1 & 1 & 1 & 1 & 1 & 1 & 1 & 1 & 1 & 1 & 1.10 \\
\hline $\mathrm{F}$ & 2 & 2 & 1 & 1 & 1 & 1 & 1 & 1 & 1 & 1 & 3 & 1 & 1 & 1 & 1 & 1 & 1 & 2 & 1 & 1 & 1.10 \\
\hline
\end{tabular}

*1 - completely unimportant factor, 2 - unimportant factor, 3 - neither important nor unimportant 4 - important factor, 5 - very important factor

1.9

**1 - very rarely, 2 - rarely, 3 - sometimes, 4 - often, 5 - very often

$\mathrm{AV}$ - average

1 - breakdowns, 2 - lack of experience, 3 - lack of commitment to work, 4 - inappropriate education 5 - utility outages, 6 - inadequate technical condition of devices, 7 - non-compliance with hygienic rules, 8 - no periodic service of devices, 9 - non-compliance with workplace procedures, 10 inadequate quality of raw materials, 11 - purchase of too many raw materials, 12 - lack of training courses, 13 - lack of relevant qualifications, 14 - incorrect internal communication, 15 - absence of suppliers' assessment, 16 - lack of raw materials quality specification, 17 - incorrect external communication, 18 - problems with selling products, 19 - inadequate production technology, 20 absence of quality management systems

Since inadequate quality of raw materials was given as one of most important factors affecting food waste (an average of 3.2), how the plants under study assess incoming supplies was analysed (Table 3). Plants D and F assessed supplies correctly whereas the most non-compliances were found in plants $\mathrm{A}$ and $\mathrm{E}$. Of least importance to the four plants was the forwarder's hygiene, whereas checking the temperature of a means of transport and/or refrigerated products and inspecting expiry dates turned out to be the key elements. 
Table 3. Frequency at which the listed actions were taken on receiving goods

\begin{tabular}{|c|c|c|c|c|c|c|c|}
\hline \multicolumn{7}{|c|}{ Please indicate frequency* at which the listed actions are taken on receiving goods } & \multirow[b]{2}{*}{ Average } \\
\hline $\begin{array}{l}\text { Plant } \\
\text { code }\end{array}$ & $\begin{array}{l}\text { Inspecting the } \\
\text { temperature of } \\
\text { a means of } \\
\text { transport } \\
\text { and/or } \\
\text { refrigerated } \\
\text { products }\end{array}$ & $\begin{array}{l}\text { Inspecting } \\
\text { the } \\
\text { forwarder's } \\
\text { hygiene }\end{array}$ & $\begin{array}{l}\text { Inspecting } \\
\text { the } \\
\text { cleanliness } \\
\text { of a means } \\
\text { of transport }\end{array}$ & $\begin{array}{c}\text { Inspecting } \\
\text { shelf life } \\
\text { dates }\end{array}$ & $\begin{array}{l}\text { Inspecting } \\
\text { the } \\
\text { condition } \\
\text { of } \\
\text { packaging }\end{array}$ & $\begin{array}{l}\text { Evaluating } \\
\text { the } \\
\text { appearance } \\
\text { and smell of } \\
\text { unwrapped } \\
\text { products }\end{array}$ & \\
\hline A & 1 & 2 & 1 & 1 & 2 & 3 & 1.7 \\
\hline $\mathrm{B}$ & 1 & 2 & 1 & 1 & 1 & 1 & 1.2 \\
\hline $\mathrm{C}$ & 1 & 2 & 1 & 1 & 1 & 1 & 1.2 \\
\hline $\mathrm{D}$ & 1 & 1 & 1 & 1 & 1 & 1 & 1.0 \\
\hline$E$ & 1 & 4 & 2 & 1 & 1 & 2 & 1.8 \\
\hline $\mathrm{F}$ & 0 & 1 & 1 & 1 & 1 & 1 & 1.0 \\
\hline Average & 1.0 & 2.0 & 1.2 & 1.0 & 1.2 & 1.5 & \\
\hline
\end{tabular}

1 *Always, 2 - Usually, 3 - Sometimes, 4 - Occasionally, 5 - Never, 0 - Not applicable

In the following stage, it was analysed how often supplies were not accepted due to the six reasons cited (Table 4). The most frequently given reason was improper temperature of a means of transport and/or refrigerated products and inadequate appearance and smell of unwrapped products. Goods were least frequently rejected owing to the forwarder's improper hygiene. It should be also noted that the above factor was least often assessed by the surveyed plants. Supplies were least frequently rejected by plant D which was also the one that assessed them correctly.

Table 4. Frequency at which foodstuff supplies were rejected due to the listed reasons

\begin{tabular}{|c|c|c|c|c|c|c|c|}
\hline \multicolumn{2}{|c|}{ Frequency* at which foodstuff supplies were rejected due to the listed reasons: } & \\
\hline $\begin{array}{c}\text { Plant } \\
\text { code }\end{array}$ & $\begin{array}{c}\text { Inadequate } \\
\text { temperature } \\
\text { of means } \\
\text { of transport } \\
\text { and/or } \\
\text { refrigerated } \\
\text { products }\end{array}$ & $\begin{array}{c}\text { Forwarder's } \\
\text { improper } \\
\text { hygiene }\end{array}$ & $\begin{array}{c}\text { Improper } \\
\text { hygienic } \\
\text { conditions } \\
\text { in means } \\
\text { of } \\
\text { transport }\end{array}$ & $\begin{array}{c}\text { Insufficiently } \\
\text { long shelf } \\
\text { life }\end{array}$ & $\begin{array}{c}\text { Inappropriate } \\
\text { condition of } \\
\text { packaging } \\
\text { appearance } \\
\text { and smell of } \\
\text { unwrapped } \\
\text { products }\end{array}$ & Average & \\
\hline A & 2 & 2 & 2 & 2 & 2 & 3 & 2.2 \\
\hline B & 1 & 2 & 2 & 2 & 2 & 2 & 1.8 \\
\hline C & 2 & 2 & 2 & 2 & 2 & 2 & 2.0 \\
\hline D & 5 & 5 & 5 & 4 & 4 & 4 & 4.5 \\
\hline E & 2 & 4 & 2 & 3 & 2 & 1 & 2.3 \\
\hline F & 0 & 5 & 4 & 4 & 4 & 3 & 3.3 \\
\hline Average & 2.4 & 3.3 & 2.8 & 2.8 & 2.7 & 2.5 & \\
\hline
\end{tabular}

1 *Always, 2 - Usually, 3 - Sometimes, 4 - Occasionally, 5 - Never, 0 - Not applicable

Next, it was examined how frequently losses occurred at each of the nine stages of production in the surveyed plants (Figure 2). As the collected data show, food losses rarely occurred in the whole production chain (average frequency was 1.8 on a 5 -point scale). 
Losses recurred most at the stage of preliminary processing and main processing, while they were hardly ever found in the course of warehousing, labelling and internal transport of products.

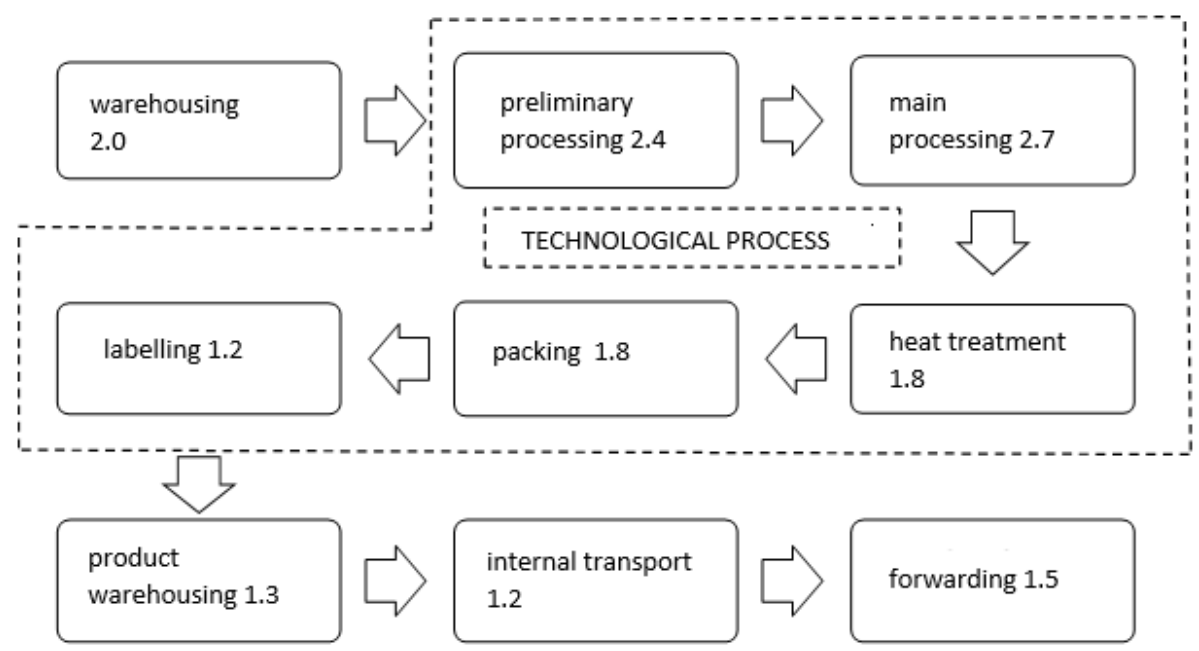

*1 - very rarely, 2 - rarely, 3 - sometimes, 4 - often, 5 - very often

Figure 2. The frequency* of food losses at individual stages

As the data show, food losses the most frequently occurred in A and C, D plants (Table 5). Plants $A$ and $D$ indicated the highest average significance of 20 factors contributing to the occurrence of food losses (Table 2). Plants A and C showed the highest average frequency of 20 factors.

Table 5. The frequency* of food losses at individual stages

\begin{tabular}{|c|c|c|c|c|c|c|c|c|c|c|}
\hline Plant code & 1 & 2 & 3 & 4 & 5 & 6 & 7 & 8 & 9 & AV \\
\hline A & 1 & 3 & 5 & 2 & 1 & 1 & 2 & 1 & 1 & 1.9 \\
\hline B & 1 & 2 & 3 & 2 & 1 & 1 & 1 & 1 & 2 & 1.6 \\
\hline C & 5 & 3 & 4 & 1 & 1 & 1 & 1 & 1 & 1 & 2.0 \\
\hline D & 2 & 2 & 1 & 2 & 2 & 1 & 2 & 2 & 2 & 1.8 \\
\hline E & 1 & 1 & 1 & 1 & 2 & 2 & 1 & 1 & 2 & 1.3 \\
\hline F & 2 & 1 & 2 & 1 & 4 & 1 & 1 & 1 & 1 & 1.6 \\
\hline
\end{tabular}

*1 - very rarely, 2 - rarely, 3 - sometimes, 4 - often, 5 - very often

1 - warehousing, 2 - preliminary processing, 3 - main processing, 4 - heat treatment, 5 - packing, 6 - labelling, 7 - product warehousing, 8 - internal transport, 9 - forwarding

AV - average

In addition, it was determined how often causes of food losses recurred at individual stages (Table 6). When a raw material was warehoused, exceeding its expiry date and breaking the cold chain happened in all the surveyed plants rarely or very rarely. What took place more often was that a raw material lost its freshness and became spoilt. It was revealed that these two reasons very often led to food losses at the stage of warehousing in the case 
of plant C (sugar production). During the technological process, the same frequency was noted in connection with products of inadequate physical and chemical parameters and products which were harmful to human health. These two causes were quoted most frequently by plant A. During the technological process, the highest average (2.0) indicating higher frequency at which they happened when compared to other reasons was found in relation to incorrect weight of products. Substantial discrepancies were shown with regard to the responses given by the surveyed. Two plants pointed to a high frequency (plant A - very often, B - sometimes), while two other plants responded with "very rarely." When a finished product was warehoused, the cold chain was very rarely broken (all plants selected "very rarely" as their response). Problems with sale due to insufficiently long shelf life dates seldom arose. The highest frequency (sometimes) was indicated by plant A, whose area of business is poultry cutting.

Also, rarely did it happen that packaging was mechanically damaged either when it came to the warehousing of goods and their forwarding. In the case of internal transport, packaging was very rarely damaged.

Rarely did it happen that the surveyed plants overproduced. The problem occurred more often in plant A, which pointed in its answer to "sometimes."

What is striking in the context of reducing food loss is what is done with raw materials and intermediary products which cannot undergo further processing, and products which cannot be designated for sale. At the stage of warehousing, raw materials which did not comply with quality requirements were collected by a specialist company and were occasionally repurposed for animal feed (plants E and F). Products harmful to human health were sent by all the plants for disposal. With regard to products of inadequate physical and chemical parameters, plants A, B and D designated them for disposal, whereas plants $\mathrm{C}$ and $\mathrm{F}$ for reprocessing. If a product was of incorrect weight or its label contained an error, plants A, B, C, and F used it for reprocessing, while plant D for disposal. Every plant followed a different procedure when problems with selling products due to insufficiently long shelf life occurred: plant A designated them for reprocessing, B - for animal feed, $\mathrm{C}$ - for sale offered to employees, $\mathrm{D}$ - for disposal, while $\mathrm{F}$ donated them to charities. The present production surpluses in plant $\mathrm{A}$ were frozen, in $\mathrm{C}$ sold to employees, while D offered them at a discount and sent them for disposal. Plant B also sent them for disposal.

Table 6. Frequency* of food loss causes at individual stages

\begin{tabular}{|c|c|c|c|c|}
\hline \multirow{2}{*}{$\begin{array}{c}\text { Plant } \\
\text { code }\end{array}$} & $\begin{array}{c}\text { Exceeding } \\
\text { shelf life }\end{array}$ & $\begin{array}{c}\text { Breaking the } \\
\text { cold chain }\end{array}$ & $\begin{array}{c}\text { Losing } \\
\text { freshness }\end{array}$ & $\begin{array}{c}\text { Visible } \\
\text { spoilage }\end{array}$ \\
\hline A & 1 & 1 & 3 & 1 \\
\hline B & 1 & 2 & 1 & 1 \\
\hline C & 1 & 1 & 5 & 5 \\
\hline D & 2 & 2 & 2 & 1 \\
\hline E & 1 & 1 & 1 & 1 \\
\hline F & 2 & 0 & 1 & 1.8 \\
\hline Average & 1.3 & 1.4 & 2.2 & \\
\hline \multicolumn{7}{r}{} \\
\hline
\end{tabular}




\begin{tabular}{|c|c|c|c|c|c|}
\hline \multicolumn{6}{|c|}{ TECHNOLOGICAL PROCESS } \\
\hline & $\begin{array}{c}\text { Incorrect } \\
\text { physical and } \\
\text { chemical } \\
\text { parameters }\end{array}$ & $\begin{array}{l}\text { Lack of health- } \\
\text { related safety }\end{array}$ & $\begin{array}{c}\text { Incorrect weight of } \\
\text { product }\end{array}$ & \multicolumn{2}{|c|}{ Errors on label } \\
\hline $\mathrm{A}$ & 5 & 5 & 5 & \multicolumn{2}{|c|}{5} \\
\hline $\mathrm{B}$ & 1 & 1 & 3 & \multicolumn{2}{|c|}{2} \\
\hline $\mathrm{C}$ & 2 & 1 & 1 & \multicolumn{2}{|c|}{1} \\
\hline $\mathrm{D}$ & 1 & 1 & 1 & \multicolumn{2}{|c|}{1} \\
\hline$E$ & 1 & 1 & 1 & \multicolumn{2}{|c|}{1} \\
\hline $\mathrm{F}$ & 1 & - & 1 & \multicolumn{2}{|c|}{1} \\
\hline Average & 1.8 & 1.8 & 2.0 & \multicolumn{2}{|c|}{1.8} \\
\hline \multicolumn{4}{|c|}{ PRODUCT WAREHOUSING AND FORWARDING } & \multicolumn{2}{|c|}{ INTERNAL TRANSPORT } \\
\hline & $\begin{array}{l}\text { Breaking the } \\
\text { cold chain }\end{array}$ & $\begin{array}{l}\text { Mechanical } \\
\text { damage to } \\
\text { packaging }\end{array}$ & $\begin{array}{c}\text { Insufficiently long } \\
\text { shelf life (problem } \\
\text { with sale) }\end{array}$ & Overproduction & $\begin{array}{l}\text { Mechanical } \\
\text { damage to } \\
\text { packaging }\end{array}$ \\
\hline A & 1 & 3 & 3 & 3 & 1 \\
\hline $\mathrm{B}$ & 1 & 2 & 2 & 2 & 2 \\
\hline $\mathrm{C}$ & 1 & 1 & 1 & 1 & 1 \\
\hline $\mathrm{D}$ & 1 & 2 & 1 & 1 & 1 \\
\hline $\mathrm{E}$ & 1 & 2 & 2 & 1 & 1 \\
\hline $\mathrm{F}$ & - & 2 & 2 & - & 1 \\
\hline Average & 1.0 & 2.0 & 1.8 & 1.6 & 1.2 \\
\hline
\end{tabular}

$* 1$ - very rarely (once a year) 2 - rarely (several times a year) 3 - sometimes (once a month) 4 often (several times a month) 5 - very often (several times a week)

\section{Discussion}

The most significant factor which contributed to food loss in the surveyed plants and which occurred most frequently was the breakdown of devices. Every enterprise has to maintain the right material resources, including equipment for processes which it carries out in order to operate efficiently. Of crucial importance is the technical condition of machinery, which should be regularly inspected. Any equipment breakdowns entail losses in raw materials, intermediary products or finished goods, but these can be prevented by systematic service and maintenance which should be included in the enterprise management system.

Inadequate quality of raw materials constitutes another key factor connected with food loss, which was determined in our study. Access to raw materials of the right quality plays a fundamental role in food production. Every plant should maintain its quality specifications for the goods it receives, which should contain information about their required features. The risk of receiving a raw material of inadequate quality is connected with, e.g. starting to work with inappropriate suppliers. Although the surveyed plants conducted supply assessment, they reported problems with the quality of the raw materials they received. It should be emphasised though that their assessment of received raw materials revealed irregularities, some of the elements of assessment were not always applied). 
All the analysed plants implemented only obligatory food safety systems, i.e. GMP/GHP and HACCP. Universal as they are, good practices are applied in every area of life, which is reflected in any actions resulting from experience and knowledge, which effectively and efficiently make the attainment of a set goal possible (Dzwolak, 2013). HACCP is an obligatory and all the same the most. effective system ensuring the health-related safety of food and its implementation must be preceded by the introduction of the principles included in Good Practices. As assessed by the surveyed plants, "the absence of quality management systems" constituted a crucial factor affecting food loss. Among nonmandatory quality management systems, the following can be listed: the quality management system according to ISO 9000, food safety management system according to ISO 22000, environmental management system according to standard 14001, the International Food Standard and the British Retail Consortium standards. Implementing non-compulsory quality management systems could prevent problems from arising in the plant and contribute to reducing food loss at the same same time.

Another aspect indicated by those surveyed, which contributed to food loss was power blackouts. Although they did not occur frequently, they were pointed to as being of considerable importance here. The above conclusion is corroborated by Raak et al. (2017) in their research conducted in thirteen plants. Plants should take preventive measures against utility outages by, e.g. maintaining an emergency power source (Bilska et al., 2016). In every plant, a key element that is the primary cause of errors is people. In this study, three factors related to employees were revealed as of equal significance, namely failure to comply with workstation procedures, the lack of training, and improper internal communication (significance at 2.7 on a 5-point scale). According to Sharif et al. (2013), inappropriate practices and poor employee knowledge contribute to the spread of diseases caught through food. As Rowell et al. (2013) found in their research, lack of communication may lead to employees neglecting good practices. Insufficient experience and inadequate qualifications may result in errors bringing about food loss. It is therefore of vital importance to improve employee skills through compulsory training, which should be organised periodically to update and reinforce their knowledge (Da Cucha et al., 2014). As Bryan (2002) noted, adequate training of all employees has a positive impact on food safety. Nonetheless, it is necessary to assess the effectiveness of training (York et al., 2009). According to Sharif et al. (2017) food industry employees do not generally use their knowledge in practice.

Food loss rarely occurred in the whole production chain in the surveyed plants. Losses recurred most at the stage of preliminary processing and main processing, while they were hardly ever found in the course of warehousing, labelling and the internal transport of products. When raw materials were warehoused, lost freshness and spoilage were the most frequent cause of food loss. Whereas when it came to production, it was incorrect weight and label errors. When products with such defaults were received, the most commonly taken course of action was having a product reprocessed (four plants). Note should be taken, however, that when a food product is safe with regard to health, but does not meet quality requirements stipulated in food law, and this is mainly incorrect labelling of products, it is admissible that such food is used for public purposes, on the condition that remedial actions are taken. One of the following solutions could possibly be adopted: removing deficiencies by producers themselves and handing the products over to a 
community organisation, handing such a product over to a community organisation, of which given lot is attached with documents specifying labelling errors and what the correct labelling should be (Kołożyn-Krajewska et al., 2017). Food loss which arises at the stage of processing and packing mainly results from the absence of technical efficiency and faults (HLPE, 2014). Errors in processing lead to finished product deficiencies such as unacceptable shape, size, weight or damaged packaging. Although this kind of faults do not affect the safety of a product (HLPE, 2014; Papargyropoulou et al., 2014), it is often used for purposes other than consumption.

Hardly ever was overproduction noted in the surveyed plants. Raak et al. (2017) claimed that overproduction rarely occurs in plants that produce goods with long shelf life dates. While Kaipia et al. (2013) observed that surplus in processed food production, particularly in the case of refrigerated food of short shelf life, constitutes one of the major causes of wasting food. The surveyed plants had numerous ways of dealing with food they could not sell owing to, e.g. too short expiry dates. A solution considered to be the best was designating such products for human consumption, which was done by two plants (selling to employees and donating to charitable organisations). Another method of handling surpluses was reprocessing (by one plant) and using products for feed. The plant producing meat products acted least appropriately: it sent the products for disposal. Similar observations were made by Raak et al. (2017) who found in their research that food surpluses were declared by the plants to be sent to factory outlets, employee canteens and charities. Some amounts were designated for animal feed or to incineration plants (for energy recovery). Nonetheless, it should be highlighted that food surpluses should first and utmost directed for human consumption through non-profit organisations (Guiseppe et al., 2014). As Schneider (2013) noted, food redistribution for people in difficult life circumstances is a great example of sustainable development, since all of the three aspects, namely the ecological, economic and social, are fulfilled. Food redistribution is a method of diminishing the gap between food waste and the lack of food safety. According to Buzba et al. (2011), a company which donates food to charitable organisations can improve its marketing image. Yet Guiseppe et al. (2014) draw attention at the fact that plants are afraid of losing their reputation when a beneficiary questions quality.

\section{Conclusions}

The conducted research determined the most crucial factors affecting food loss in the surveyed food processing plants and showed how frequently the losses occurred. In addition, it suggested measures that should be taken to mitigate the risk of situations leading to food loss. The factors that were identified can be divided into three groups: those connected with employees, with technical aspects, and with quality.

It was found that losses at individual stages of the production chain occurred at a low frequency. It should be also pointed out that ways of dealing with food surpluses were not always the best-chosen methods. Without any doubt, products which are safe and of the right quality should be directed for consumption. In the food waste hierarchy, of priority importance are measures mitigating the risk of food loss occurrence, which are followed by donating food surpluses to charities.

Currently, there are few studies in the subject literature related food loss in food processing 
plants. It is therefore necessary to undertake further research which will provide a variety of data about both the amount of wasted food and its causes. These research results will then be used to develop strategies for reducing losses at the stage of processing.

The results of the study have an ethical constraint. In case of unethical practices from the management of this plants, it will never come on surface through survey study. This should be considered as limitation of this study. The data should be crosschecked with the food safety and related regulatory bodies reports. It could be the potential topic for future research.

\section{Funding}

This publication has been developed under the contract with the National Center for Research and Development No Gospostrateg1/385753/1/NCBR/2018 for carrying out and funding of a project implemented as part of the "The social and economic development of Poland in the conditions of globalizing markets - GOSPOSTRATEG" programme called "Developing a system for monitoring wasted food and an effective program to rationalize losses and reduce food wastage" (acronym PROM).

\section{References}

Bilska, B., Wrzosek, M., Kołożyn-Krajewska, D., \& Krajewski, K. (2016). Risk of food losses and potential of food recovery for social purposes. Waste Management, 52, 269-277.

Bryan, F.I., (2002). Where we are in retail safety, how we got to where we are, and how we get there? Journal of Environmental Health, 65, 29-36.

Commission Staff Working Document, impact assessment on measures addressing food waste to complete swd (2014). 207 regarding the review of EU waste management targets. https://ec.europa.eu/environment/eussd/pdf/IA.PDF. Accessed 20/07/2019.

Da Cunha, D.T., Stedefeldt, E., \& de Rosso, V.V. 2014). The role of theoretical food safety training on Brazilian food handlers' knowledge, attitude and practice. Food Control, 43, 167-174.

Dzwolak, W. (2013). Dobre praktyki rolnicze GAP w produkcji roślinnej i zwierzęcej. Przemysł Spożywczy, $67,32-34$.

EU Sustainable Development Strategy https://ec.europa.eu/environment/sustainabledevelopment/strategy/index_en.htm. Accessed 20/08/2019.

Guiseppe, A., Mario, E., \& Cinzia, M. (2014). Economic benefits from food recovery at the retail stage: an application to Italian food chains. Waste Management, 34 (7), 1306-16.

Gustavsson, J., Cederberg, C., Sonesson, U., Van Otterdijk, R., \& Meybeck, A., (2011). Global food losses and food waste. Extent, Causes and Prevention. Gothenburg, Rome: Swedish Institute for Food and Biotechnology (SIK), FAO.

HLPE . Food Losses and Waste in the Context of Sustainable Food Systems. A Report by the High Level Panel of Experts on Food Security and Nutrition of the Committee on World Food Security. Committee on World Food Security; Rome, Italy: 2014

Kaipia, R., Dukovska-Popovska, I., \& Loikkanen, L. (2013). Creating sustainable fresh food supply chains through waste reduction. International Journal of Physical Distribution \& Logistics Management, 43:262-276.

Kołożyn-Krajewska, D., Bilska, B., Krajewski, K., Wrzosek, M., (2017). Ograniczenie strat i marnotrawstwa żywności - kontekst prawny i prace w Polsce nad modelem MOST. Food Lex, 3, 45-50.

Papargyropoulou, E., Lozano R., Steinberger, J.K., Wright, N., \& Ujang, Z.B. (2014). The food waste hierarchy as a framework for the management of food surplus and food waste. Journal of Cleaner Production, 76, 106-115. 
Raak, N., Symmank, C., Zahn, S., Aschemann-Witzel, J., \& Rohm, H. (2017). Processing and product-related causes for food waste and implications for the food supply chain. Waste Management, 61, 461-472.

Report of the World Commission on Environment and Development: Our Common Future. (1987). https://sustainabledevelopment.un.org/content/documents/5987our-common-future.pdf. Accessed 20/07/2019.

Rowell, A.E., Binkley, M., Alvarado, C., Thompson, L., \& Burris, S. (2013). Influence of food safety training on grocery store employees' performance of food handling practices. Food Policy, 41, 177-183

Sharif, L., Obaidat, M. M., \& Al-Dalalah, M. R. (2013). Food hygiene knowledge, attitudes and practices of food handlers in the military hospitals. Food \& Nutrition Sciences, 4, 245-251.

Schneider, F., (2013). The evolution of food donation with respect to waste prevention Waste Management, $33,755-763$.

York, V., Brannon, L., Shanklin, C., Roberts, K., Barrett, B. and Howells, A. (2009), Intervention improves restaurant employees' food safety compliance rates. International Journal of Contemporary Hospitality Management, 21 (4), 459-478. 